\title{
Csontvelő-biopsziából diagnosztizált szisztémás oxalosis
}

\section{Systemic oxalosis diagnosed on bone marrow biopsy}

\author{
Nagy Ágnes ${ }^{1, @}$, Kardos Magdolna ${ }^{2}$, Fintha Attila ${ }^{1}$, Istenes Ildikó ${ }^{3}$, \\ Somogyi Dóra ${ }^{4}$, Csomor Judit ${ }^{1}$ \\ 'Semmelweis Egyetem, I. sz. Patológiai és Kísérleti Rákkutató Intézet, Budapest \\ ${ }^{2}$ Semmelweis Egyetem, II. sz. Patológiai Intézet, Budapest \\ ${ }^{3}$ Semmelweis Egyetem, I. sz. Belgyógyászati és Onkológiai Klinika, Budapest \\ ${ }^{4}$ Semmelweis Egyetem, Transzplantációs és Sebészeti Klinika, Budapest
}

(Beérkezett: 2020. július 20.; elfogadva: 2020. szeptember 14.)

Az 58 éves nőbeteg kisgyermekkorban kezdődő krónikus pyelonephritis, vesekövesség (kalcium-oxalát kövek) és nephrocalcinosis okozta veseelégtelenség miatt 2018 áprilisában vesetranszplantáción esett át (veseeltávolítás nem történt). Két hónappal a transzplantációt követően romló vesefunkciót (kreatinin $113 \mu \mathrm{mol} / \mathrm{L}$, karbamid
8,0 $\mathrm{mmol} / \mathrm{L})$, hypalbuminémiát, albuminuriát, proteinuriát észleltek. Szérum immunfixáció kis mennyiségü monoklonális IgG kappa típusú fehérje jelenlétét igazolta. A szérumban a szabad könnyúláncok mennyisége emelkedett volt (kappa 48,30 mg/L, lambda 44,50 mg/L), de a kappa/lambda arány a normál tartományba esett.

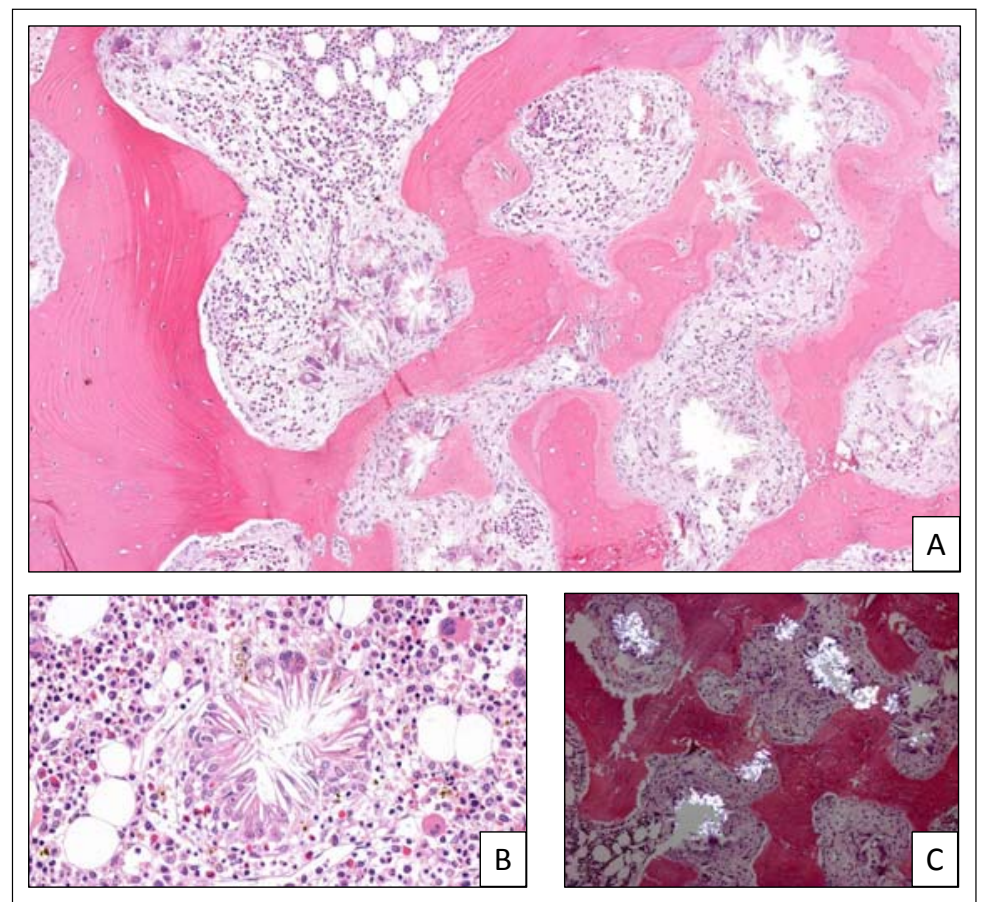

1. ábra. (A) Csontvelő átnézeti kép: csontszerkezeti átépülést és fibrosist okozó, intertrabecularisan elhelyezkedő oxalát "granulomák” (Hematoxilin-eozinfestés, 90x nagyítás). (B) Kaszakő alakú, rozettákat formáló kalcium-oxalát kristályok, amelyek körül histiocyták és idegentest típusú óriássejtek láthatók (Hematoxilin-eozinfestés, 400× nagyítás). (C) A kristá-

lyok polarizált fényben kettős törést mutatnak (Hematoxilin-eozinfestés, polarizációs mikroszkóp, 100× nagyítás)

@ Levelezési cím: Dr. Nagy Ágnes, I. sz. Patológiai és Kísérleti Rákkutató Intézet, 1085 Budapest, Üllói út 26.; E-mail: agnes93nagy@gmail.com 


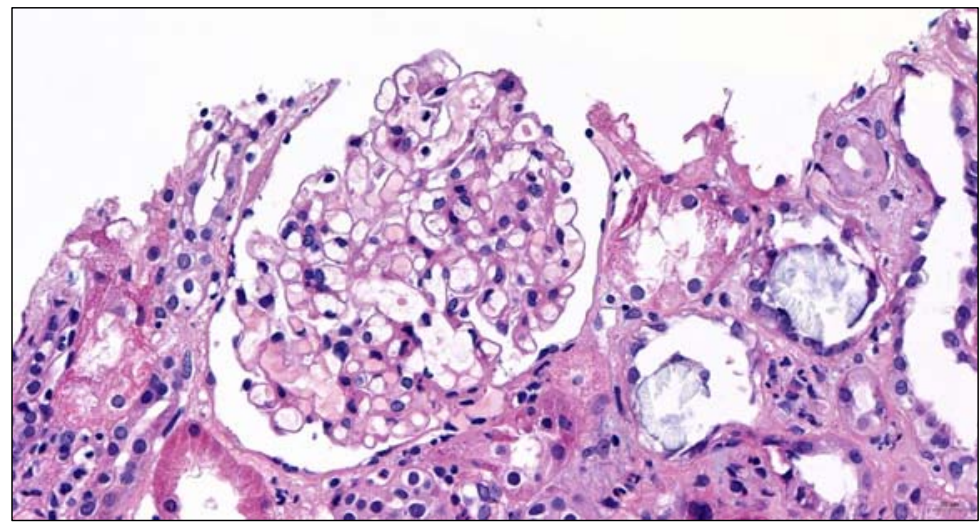

2. ábra. Kalcium-oxalát kristályok jelenléte a transzplantált veséből származó biopsziában (Hematoxilin-eozinfestés, 400× nagyítás)

A laboreltérések és a 2017 óta ismert kompressziós csigolyatörés miatt myeloma kizárására cristabiopsziát végeztek. A cristabiopszia szövettani vizsgálata során monoklonális plazmasejtbetegség nem igazolódott, a csontvelö plazmasejtaránya 5-10\% között volt, poliklonális intracitoplazmatikus könnyülánc jelölődéssel. „Meglepetésként" a csontvelőben normál vérképzést mutató területek mellett, kiterjedt, csontstruktúra-átépülést és fibrózist okozó, kalcium-oxalát kristályok indukálta granulomatosus osteomyelitist észleltünk (1. ábra).

$\mathrm{Az}$ anamnézis és az extrarenális érintettség alapján primer hyperoxaluria $(\mathrm{PH})$ lehetőségét vetettük fel. A szekunder oxalosishoz vezetó állapotokat - magas oxaláttartalmú diéta, zsír malabszorpció, intestinális oxalátlebontó mikroorganizmusok csökkent jelenléte [1] - a klinikai vizsgálatok kizárták. Annak ellenére, hogy a diagnózis igazolásához szükséges genetikai vizsgálatra és a máj enzimológiai elemzésére nem került sor, és az oxalátürítés mértéke sem érte el a diagnosztikus értéket ( $>1 \mathrm{mmol} /$ $1,73 \mathrm{~m}^{2} / \mathrm{nap}$ ), diagnózisunkat tovább erősítette a prog- resszíven romló vesefunkció miatt végzett vesebiopszia, ami a transzplantált vese tubulusaiban is extenzív kalcium-oxalát-lerakódást mutatott. (2. ábra)

A PH ritka, autoszomális recesszíven öröklődő betegség, amelynek három altípusa ismert. A három altípus közös jellemzője a glioxalát metabolizmus zavara, amelynek következménye a megnövekedett oxalátképződés. Az oxalát a kalciummal oldhatatlan kristályt képez, ami elsősorban a vesében, később extrarenális szövetekben, pl. a csontvelőben rakódik le [2-4].

$\mathrm{Az}$ I. típusú PH klinikai megjelenése nagyon heterogén, különböző életkorban (1-60 év) okozhat tüneteket, súlyos hyperoxaluriát, recidív vesekövességet és/vagy kövesség nélküli progresszív nephrocalcinosist, amely a betegek nagy részénél veseelégtelenséghez és szisztémás oxalosishoz vezet. A diagnózis gyakran későn, a veseelégtelenség kialakulása után születik meg (az esetek több mint 30\%-ában) [5, 6]. A II. típusú PH-ra általában jellemző a későbbi kezdet, a tünetek enyhébb lefolyása és a veseelégtelenség későbbi kialakulása [7]. A III. típus leg-

1. táblázat. Primer hyperoxaluria típusainak és a saját esetünk jellegzetességeinek összehasonlítása

\begin{tabular}{|c|c|c|c|c|}
\hline & I. típusú PH & II. típusú PH & III. típusú PH & Saját eset \\
\hline Érintett gén, enzim & $\begin{array}{l}A G X T \text {, alanin glioxalát } \\
\text { aminotranszferáz }\end{array}$ & $\begin{array}{l}G R H P R \text {, glioxalát } \\
\text { reduktáz/hidroxipiruvát } \\
\text { reduktáz }\end{array}$ & $\begin{array}{l}H O G A 1, \text { 4-hidroxi- } \\
\text { 2-oxo-glutarát aldoláz }\end{array}$ & nem vizsgálták \\
\hline PH eloszlása & $80 \%$ & $10 \%$ & $10 \%$ & - \\
\hline $\begin{array}{l}\text { Első tünetek } \\
\text { megjelenése }\end{array}$ & $\begin{array}{l}\text { általában gyermekkor- } \\
\text { ban, de csecsemőkortól } \\
60 \text { éves korig bármikor } \\
\text { jelentkezhet }\end{array}$ & gyermekkorban & $\begin{array}{l}\text { gyermekkorban } \\
\text { (legkorábban ebben } \\
\text { a csoportban [9]) }\end{array}$ & kisgyermekkorban \\
\hline $\begin{array}{l}\text { Tünetek (nephrolithi- } \\
\text { asis, nephrocalcinosis) }\end{array}$ & általában súlyos & kevésbé súlyos & $\begin{array}{l}\text { legenyhébb, főleg } \\
\text { nephrolithiasis, ritkán } \\
\text { nephrocalcinosis }\end{array}$ & $\begin{array}{l}\text { recidív nephrolithiasis, } \\
\text { progresszív nephrocal- } \\
\text { cinosis }\end{array}$ \\
\hline Szisztémás oxalosis & igen & általában igen & nem jellemző & igen \\
\hline $\begin{array}{l}\text { Veseelégtelenség } \\
\text { kialakulása }\end{array}$ & $\begin{array}{l}\text { igen (leggyakrabban } \\
30-50 \text { év között) }\end{array}$ & $\begin{array}{l}\text { igen (későbbi életkor- } \\
\text { ban és kisebb arányban) }\end{array}$ & általában nem & igen (58 éves korban) \\
\hline Transzplantáció & kombinált máj és vese & vese & általában nem szükséges & vese \\
\hline
\end{tabular}


gyakrabban gyermekkortól jelentkező vesekövességgel jár, de veseelégtelenséget ritkán okoz [8]. Konzervatív terápia - extrém folyadékbevitel, kalcium-oxalát kristályképződést (kálium- vagy nátrium-citrát), illetve oxalátbioszintézist gátló (piridoxin) kezelés - a veseelégtelenség kialakulását lassíthatja. A végleges gyógyulást a betegség típusától függően kombinált vagy egymást követő máj-vese (I. típusú PH-ban) vagy izolált vesetranszplantáció (II. típusú PH-ban) hozhatja meg. Az egyes típusok jellemzőit, összehasonlítva a saját esetünkkel az 1. táblázatban foglaltuk össze.

$\mathrm{Az}$ egyes altípusok heterogén megjelenése és átfedő tünettana miatt, genetikai vizsgálat hiányában, esetünk teljes biztonsággal nem sorolható be egyik altípusba sem. A klinikai lefolyás és tünettan, illetve az oxalátkristályok korai, újbóli megjelenése a transzplantáció utáni vesében az I-es típust valószínüsítik. A primer hyperoxaluria ritka betegség, de korai gyermekkorban kezdődő vesekövesség, recidiváló oxalátkövesség esetén mindig gondolni kell rá. A korai diagnózis és megfelelő kezelés lehetővé teheti a további komplikációk, mint a csontvelői oxalosis kialakulásának megelőzését, illetve meghosszabbíthatja a transzplantáció nélkül leélt éveket. Esetünk felhívja a figyelmet arra, hogy a csontvelő vizsgálata nemcsak hematológiai jellegü eltérések, hanem különböző granulomatosus betegségek, csontbetegségek, tárolási betegségek, autoimmun kórképek, infekciók és szolid tumorok másodlagos csontérintettségének diagnosztikájában is értékes lehet.

Nyilatkozat: A kézirat korábban más folyóiratban nem jelent meg és máshova beküldésre nem került. A szerzők anyagi támogatásban nem részesültek.

Érdekeltségek: A szerzőknek nincs a közleményhez kapcsolódó közvetlen érdekeltségük.
Szerzői munkamegosztás: N.Á., K.M., F.A., I.I., S.D., Cs.J.: a kézirat elkészítése; N.Á., K.M., F.A., Cs.J.: az ábraanyag képeinek összeállítása. A kézirat végleges változatát minden szerző elolvasta és jóváhagyta.

\section{Irodalom}

[1] Karaolanis GI, Lionaki S, Moris D, Palla V, Vernadakis S. Secondary hyperoxaluria: a risk factor for kidney stone formation and renal failure in native kidneys and renal grafts. Transplantation Reviews 2014; 28(4): 182-187.

[2] Nematollahi P, Mohammadizadeh F. Primary hyperoxaluria diagnosed based on bone marrow biopsy in pancytopenic adult with end stage renal disease. Case Rep Hematol. 2015; 2015: 402947.

[3] Nachite F et al. Primary hyperoxaluria detected by bone marrow biopsy: Case report. BMC Clin Pathol. 2017 Sep 20; 17: 20.

[4] Sharma S et al. Bone marrow oxalosis: An unusual cause of cytopenia in end-stage renal disease; report of two cases. Indian J Pathol Microbiol. 2018; 61: 268-70.

[5] Hoppe B. An update on primary hyperoxaluria. Nat Rev Nephrol. 2012; 8: 467-475.

[6] Milliner DS, Harris PC, Cogal AG, et al. Primary Hyperoxaluria Type 1. 2002 Jun 19 [Updated 2017 Nov 30]. In: Adam MP, Ardinger HH, Pagon RA, et al. (eds). GeneReviews ${ }^{\circ}$ [Internet]. Seatthe (WA): University of Washington, Seattle; 1993-2020. Available from: https://www.ncbi.nlm.nih.gov/books/NBK1283/

[7] Rumsby G, Hulton SA. Primary Hyperoxaluria Type 2. 2008 Dec 2 [Updated 2017 Dec 21]. In: Adam MP, Ardinger HH, Pagon RA, et al. (eds). GeneReviews ${ }^{\circ}$ [Internet]. Seattle (WA): University of Washington, Seattle; 1993-2020. Available from: https://www. ncbi.nlm.nih.gov/books/NBK2692/

[8] Milliner DS, Harris PC, Lieske JC. Primary Hyperoxaluria Type 3. 2015 Sep 24. In: Adam MP, Ardinger HH, Pagon RA, et al. (eds). GeneReviews $^{\circ}$ [Internet]. Seattle (WA): University of Washington, Seattle; 1993-2020. Available from: https://www.ncbi.nlm. nih.gov/sites/books/NBK316514/

[9] Hopp K, Cogal AG, Bergstralh EJ, et al. Phenotype-genotype correlations and estimated carrier frequencies of primary hyperoxaluria. J Am Soc Nephrol. 2015; 26(10): 2559-2570.

A cikk a Creative Commons Attribution 4.0 International License (https://creativecommons.org/licenses/by/4.0/) feltételei szerint publikált Open Access közlemény, melynek szellemében a cikk bármilyen médiumban szabadon felhasználható, megosztható és újraközölhető, feltéve, hogy az eredeti szerző és a közlés helye, illetve a CC License linkje és az esetlegesen végrehajtott módosítások feltüntetésre kerülnek. (SID_1) 